\title{
The Effectiveness of Eco pedagogy based IPS Electronic Module in improving Attitudes Caring for the Environment of students of Islamic School, Diponegoro, Surakarta
}

\author{
Mutiara Danirmala, Asrowi, Akhmad Arif Musadad
}

Master Program in Educational Technology Study Program, Sebelas Maret University, Jl. Ir Sutami No 36 Surakarta, Indonesia

Received: 2 Oct 2020; Received in revised form: 12 Nov 2020; Accepted: 18 Nov 2020; Available online: 26 Nov 2020

(C)2020 The Author(s). Published by Infogain Publication. This is an open access article under the CC BY license

(https://creativecommons.org/licenses/by/4.0/).

\begin{abstract}
This study aims to produce teaching materials in the form of electronic modules based on ecopedagogy that are valid, practical and effective for students' environmental care attitudes in social studies subjects. This research is included in research and development (Research and Development) which refers to the ADDIE development model which includes the Analysis, Design, Development, Implementation, Evaluation stages. Ecopedagogy-based electronic module testing in learning and environmental care attitude tests were carried out on seventh-grade students of Diponegoro Islamic Middle School, Surakarta. The trial design of this study used the One Group Pretest-Posttest Design. The results showed that the average percentage of the feasibility value in terms of material and media was 4.4 with very feasible criteria. The use of an ecopedagogy-based electronic module in the limited trial from the teacher is 4.8 and the students get an average score of 4.6 with the very practical category. Ecopedagogybased electronic modules are effective in improving students' environmental care attitudes marked by an increase in caring attitudes towards the environment from 70.9 to 89.1. These results indicate that the developed ecopedagogy-based electronic module has valid, practical and effective criteria.
\end{abstract}

Keywords-Electronic Module, Social Studies, Ecopedagogy, Environmental Care.

\section{INTRODUCTION}

Ecological problems are one of the problems that are often discussed today. This occurs due to reduced human awareness of the importance of the environment so that it needs to be preserved and preserved. It is strengthened by the existence of globalization which enables all human beings to relate to other humans very easily, effectively and efficiently, resulting in excessive exploitation of nature. For example, large-scale clearing of forests to open new jobs in the oil palm plantation sector, construction of roads that require expansion by clearing forests or rice fields, and disposing of garbage and factory waste to pollute river flow (Nasution, et al, 2016: 141).

Based on this, the human obligation to interact with the environment must be based on an attitude of responsibility to protect and preserve the environment. As Ward \& Dubos stated that the earth is only one (only one ISSN: $2456-7620$ earth) whose survival is very dependent on humans to protect and preserve the environment. The current global crises can be traced from a human perspective regarding environmental exploitation without considering environmental sustainability. Various environmental problems such as global warming, depletion of the ozone layer, environmental damage, the crisis of natural resources, environmental pollution, reduction of biodiversity, forest fires, floods, erosion, etc. occur on a local, national and global scale.

Cultivating a caring attitude towards the environment can be done through education taught in schools, especially in social studies subjects (Kollmuss\&Agyeman, 2010: 239). Environmental education in social studies lessons is integrated into every social study learning structure. Geographical, economic, sociological, and historical studies in social studies can all 
be integrated with environmental competencies and materials. This ecological problem can be used as an interesting study and taught to students. So far, social studies learning which is monotonous and dominant in the mastery of the cognitive aspects causes students to be less interested in learning social studies, so it is necessary to innovate in the media and learning resources used by the teacher. This is done so that the essence of social studies learning becomes meaningful learning, and is not limited to memorization and other cognitive aspects.

By cultivating an attitude of caring for the environment in schools, it is hoped that students can implement it in social life per the mission of the Ministry of Environment of the Republic of Indonesia and the proper social studies learning objectives. Thus schools can help students to understand the environment, concern for the earth, the impact of development, and sustainable life in the future (Ozsoy, 2013: 3). But the facts in the field based on the results of observations and interviews, students have not been able to see environmental problems with a positive and proactive attitude. This condition was strengthened by questionnaires distributed to 80 students and the results obtained were 31 students or $39 \%$ of students had an environmental concern and 49 students or $61 \%$ of their environmental concerns were still lacking.

So the effort made to address this is the need for education or a learning process in society, especially the younger generation. The young generation has a very crucial position. Because based on the current conditions, namely that children are closer to technology and far from the natural environment (Hadzigeorgiou\&Skoumios, 2013: 406), so facing these challenges, it is important to introduce the younger generation to the knowledge of skills and the right attitudes related to the environment (Sarkar \& Ara, 2007: 124). This fact makes the integration of an environmental care attitude needed to preserve the environment. Environmental care is one of the 18 values in character education that have been integrated into the applicable curriculum from primary to tertiary education.

Based on the conditions described above, it is deemed necessary to develop teaching materials in the form of electronic modules based on ecopedagogy in social studies as an effort to improve students' caring attitudes towards the environment. This is by the opinion of Supriatna, (2016: 287-288) that ecopedagogy is an alternative approach to educating students and communities to learn to live more justly, in harmony with nature and to maintain the values of local wisdom embraced by society and the preservation of nature to support civilization. sustainable to change the relationship between humans and the environment today.

\section{METHOD}

This research is included in research and development (Research and Development), namely research that is used to produce certain products (creations) and to test the effectiveness of these products (Sugiyono: 2018). The product in question is an electronic module based on ecopedagogy in social studies learning to improve students' environmental care attitudes. The development of an ecopedagogy-based electronic module in this study refers to the ADDIE development model which includes the Analysis, Design, Development, Implementation, Evaluation stages (Dick, W., Carey: 2009). The ecopedagogy-based electronic module product developed was validated by a team of experts. Validation data from experts are analyzed qualitatively as input to improve the product being developed. Questionnaire data regarding expert responses regarding the feasibility of product development were analyzed by transforming the average score of all observed aspects into qualitative sentences with the criteria as in the following table.

Table 1. Conversion Level of Achievement of Expert Team Validation

\begin{tabular}{|c|c|c|}
\hline Mastery Level & Interpretation & Information \\
\hline $82-100 \%$ & Very Good & Very Feasible \\
\hline $63-81 \%$ & Good & Feasible \\
\hline $44-62 \%$ & Pretty Good & Lack Feasible \\
\hline $25-43 \%$ & Lack & Not Feasible \\
\hline $\begin{array}{l}\text { (So } \\
\text { difications) }\end{array}$ & Sudjana, & 2005: \\
\hline
\end{tabular}

While the analysis of students' environmental care attitudes is presented in the following table:

Table 2. Categories of Environmental Care Attitudes

\begin{tabular}{cc}
\hline Categories & Information \\
\hline $82-100$ & Environmental Care \\
\hline $63-81$ & Care Enough for Environmental Care \\
\hline $44-62$ & No Matter for Environment \\
\hline $25-43$ & Very Doesn't Care for the \\
& Environment \\
\hline
\end{tabular}

(Source: Sudjana, 2005: 47 with modifications)

\section{RESULTS AND DISCUSSION}

\subsection{The Results of the Analysis Phase}

The analysis stage is the initial stage in developing an electronic module based on ecopedagogy. At this stage, several activities were carried out, namely analyzing the 
problems and needs of students and analyzing basic competencies. Problem analysis is carried out to determine basic problems in the development of an ecopedagogybased electronic module. In this step, the researcher generally observes the problems that arise in the VII grade social studies learning at Diponegoro Islamic Junior High School, Surakarta. Analysis of the needs of students, namely students needing innovations in social studies learning that can increase students' sense of care for the environment, this innovation is offered by researchers, namely with an electronic module based on ecopedagogy where abstract material can be explained by media components consisting of, interactive media, pictures, animation and learning videos.

Basic competency analysis stipulates that the material developed focuses on Basic Competencies (3.3 Analyzing the concept of interaction between humans and space to produce various potentials of Indonesian natural and maritime resources (production, distribution, consumption, supply-demand) and interactions between spaces for the sustainability of economic, social and economic life. Indonesian culture and (3.4 Presenting the results of an analysis of the concept of interaction between humans and space to produce various potentials of Indonesian natural and maritime resources (production, distribution, consumption, demand and supply) and interactions between spaces for the sustainability of Indonesia's economic, social and cultural life ).

\subsection{The Results Of The Planning Stage}

This stage is a systematic process that begins with compiling a storyboard as a basis and an overview of the form, content, appearance in developing an electronic module based on ecopedagogy. In this stage, supporting content is collected in the development of an electronic module based on ecopedagogy. Following are the results of the storyboard design.

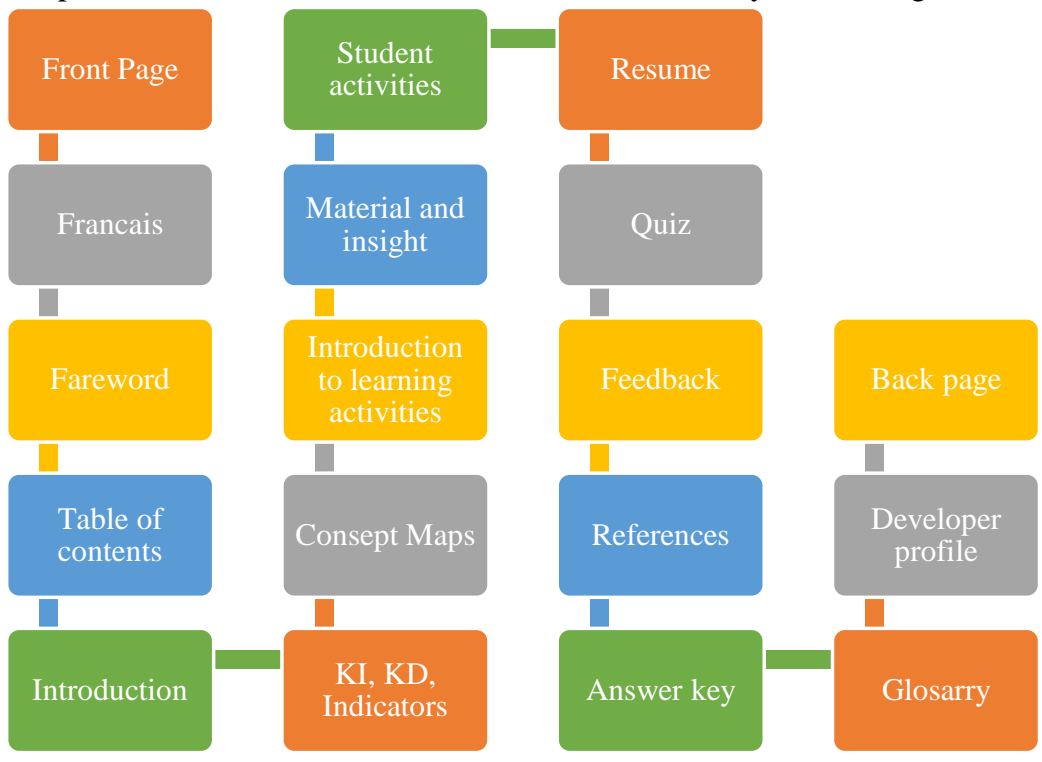

Fig.1: Content Format (Storyboard) of the Electronic IPS Module Based on Ecopedagogy

\subsection{The Results Of The Development Stage}

This stage is the stage of making an electronic module based on ecopedagogy which is developed containing cover pages, francais and forewords, table of contents, introduction and $\mathrm{KI}, \mathrm{KD}$, indicators, concept maps and introduction to learning activities, material and insight, student activities, environmental sustainability concepts /ecopedagogy, summaries, quizzes, feedback and reference lists. The developed ecopedagogy-based electronic module contains material with characteristics and abstracts explained with illustrations, pictures and learning videos to be able to train students' caring attitudes towards the environment. The development results can be seen in Table 3 below. 
Table 3. Display of Ecopedagogy Based Electronic Modules and Information

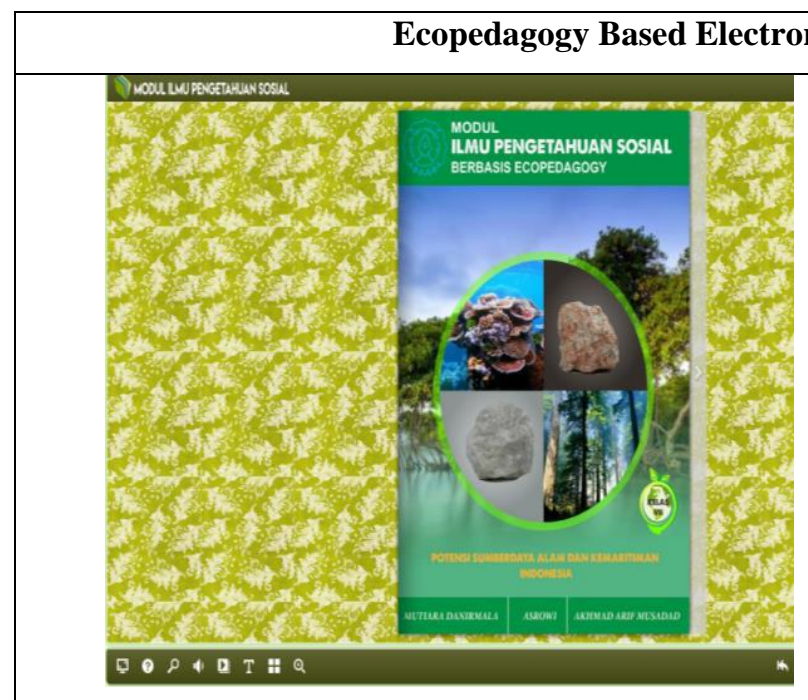

Fig.1: Front page / cover as the initial display of the Social

Science electronic module based on ecopedagogy

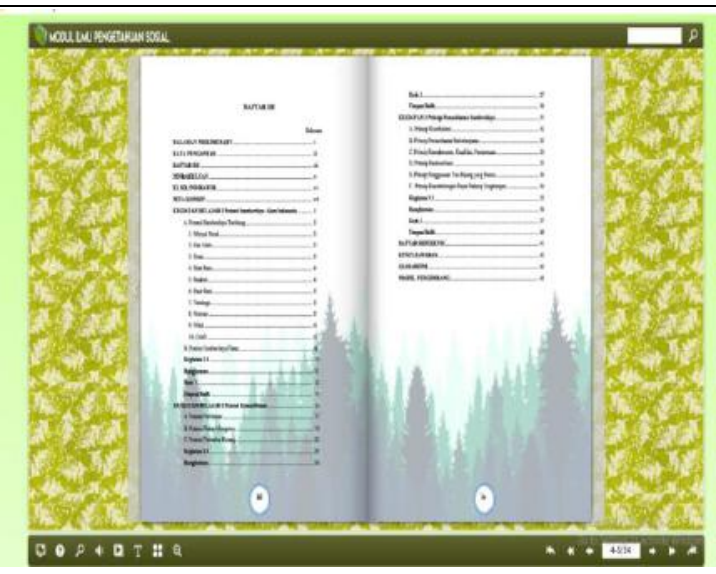

Contents contains brief details of the electronic module contents and their pages. This makes it easier for users to find the material they want to study.

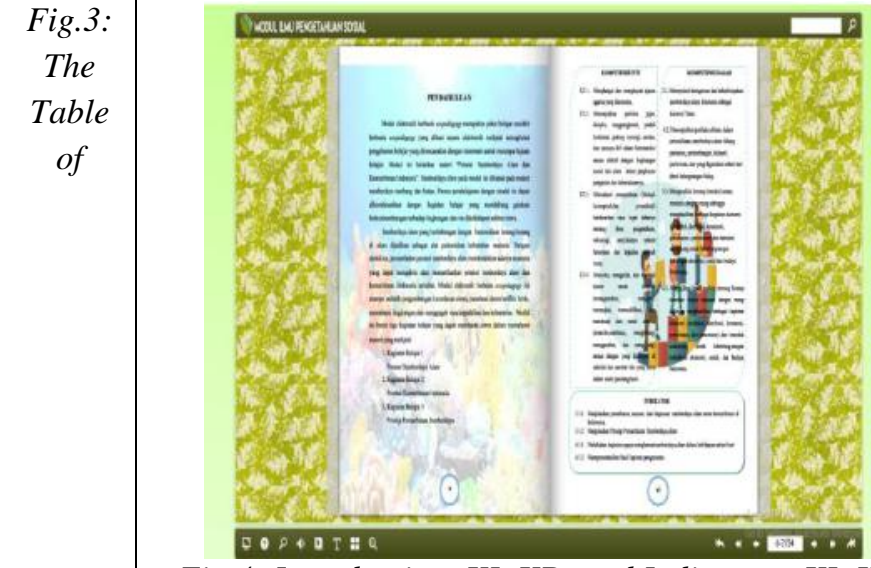

Fig.4: Introduction, $K I, K D$, and Indicators. $K I, K D$, and indicators are included in this ecopedagogy-based social science electronic module so that users know the learning objectives of the material being studied

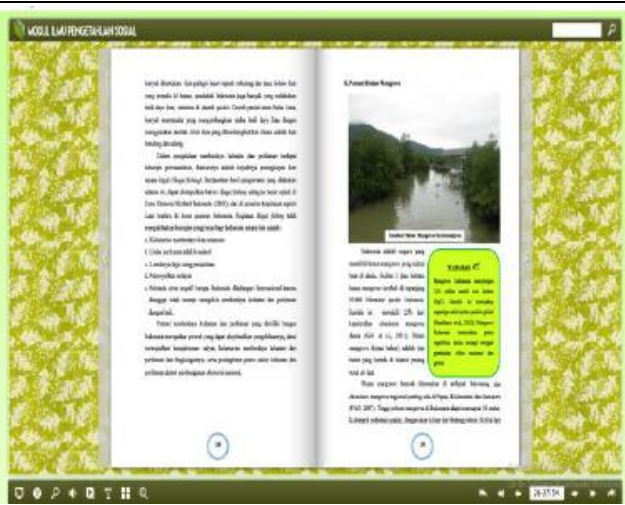

Fig.6: Material and insight. The material is presented in accordance with the applicable curriculum, namely the 2013 curriculum at the junior high school level 


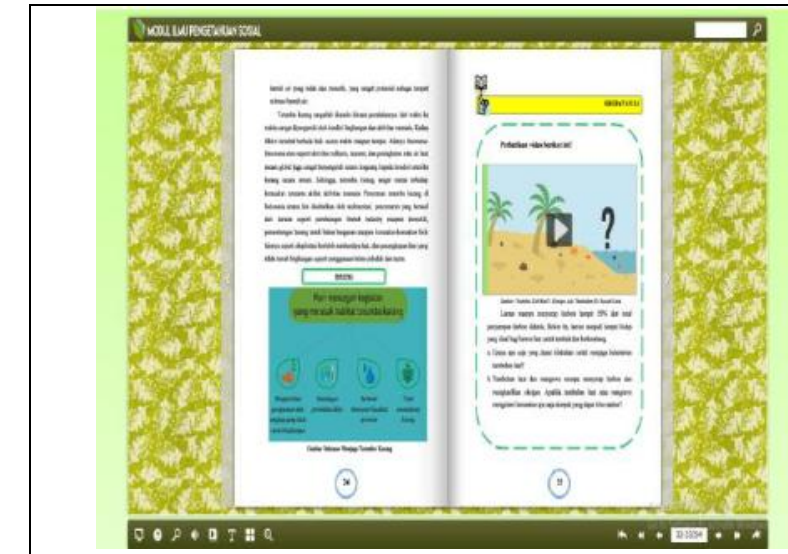

Fig.7: Student activities are in the form of assignments presented with instructional videos to make them more interesting and able to hone students' thinking skills.

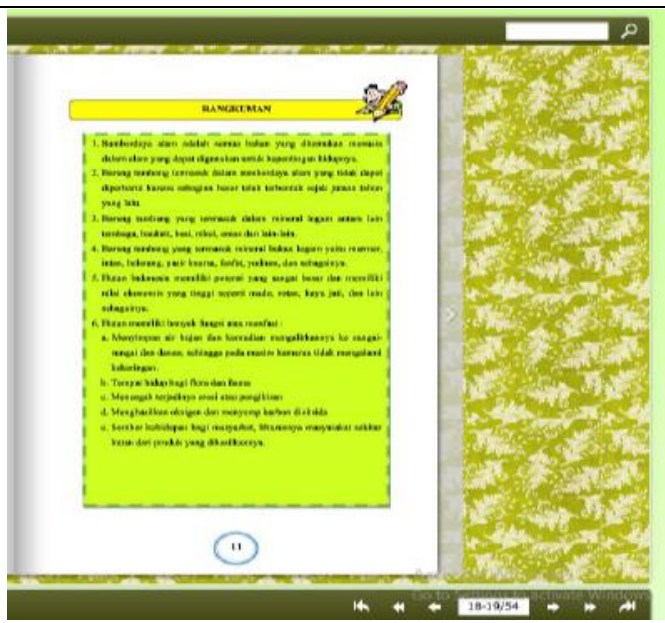

Fig.9: A summary of the material is presented, so that it is easy for users to find out the outline of each activity.

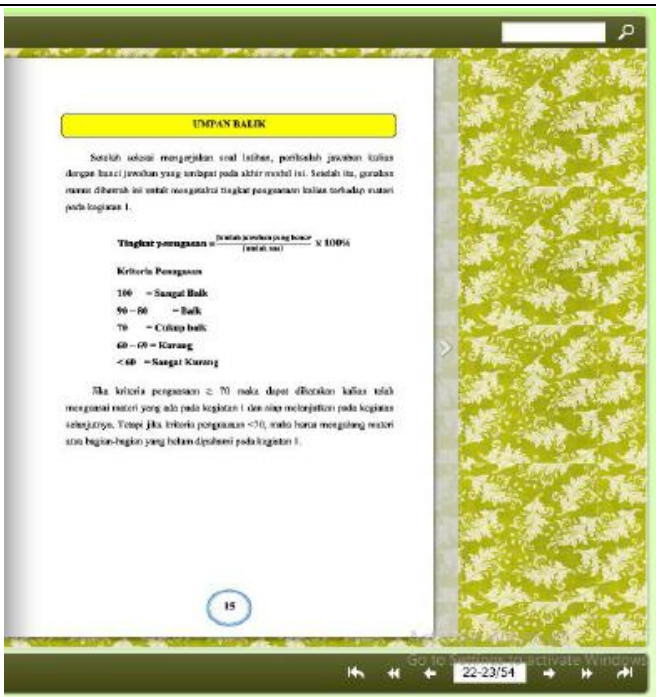

Fig.11: Feedback contains assessment rules that can be done independently by the user.

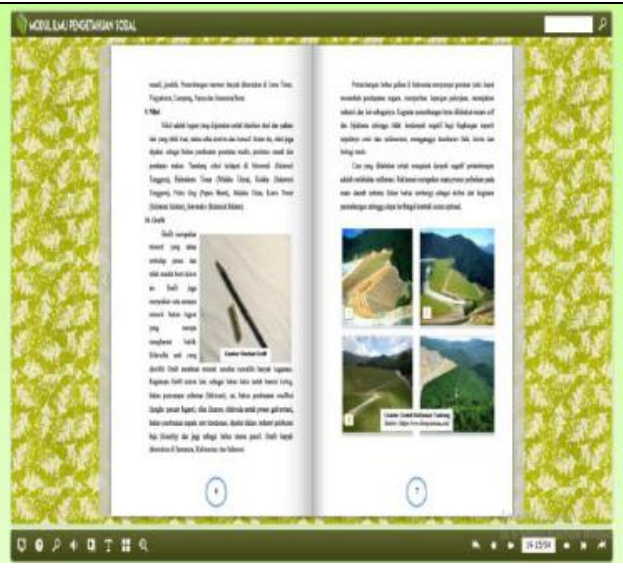

Fig.8: The ecopedagogy concept used in this electronic module is based on the NEP so that it can stimulate a caring attitude towards the environment

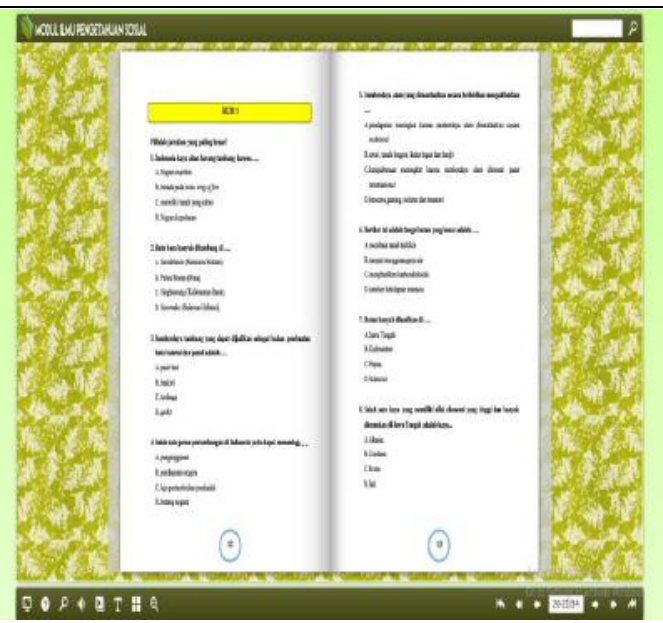

Fig.10: Quizzes are given as a measure whether the user understands each activity in the electronic module.

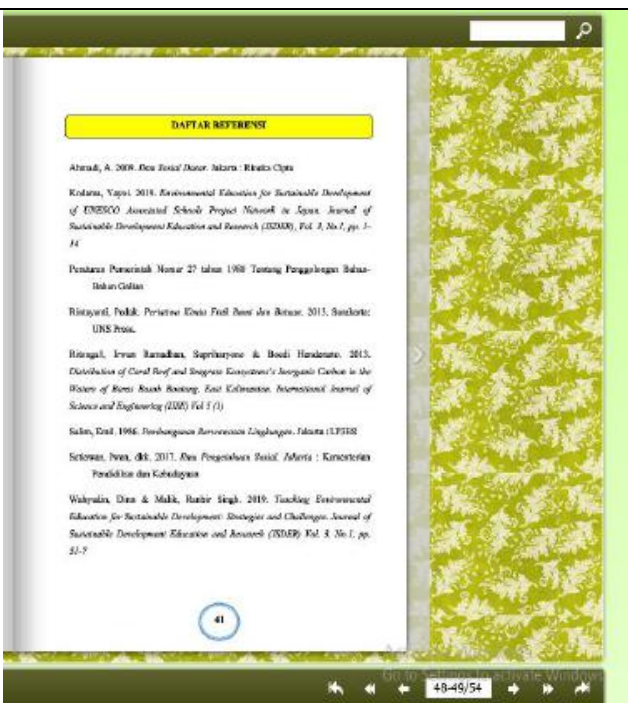

Fig.12: The reference list contains the citation sources used in the module. 


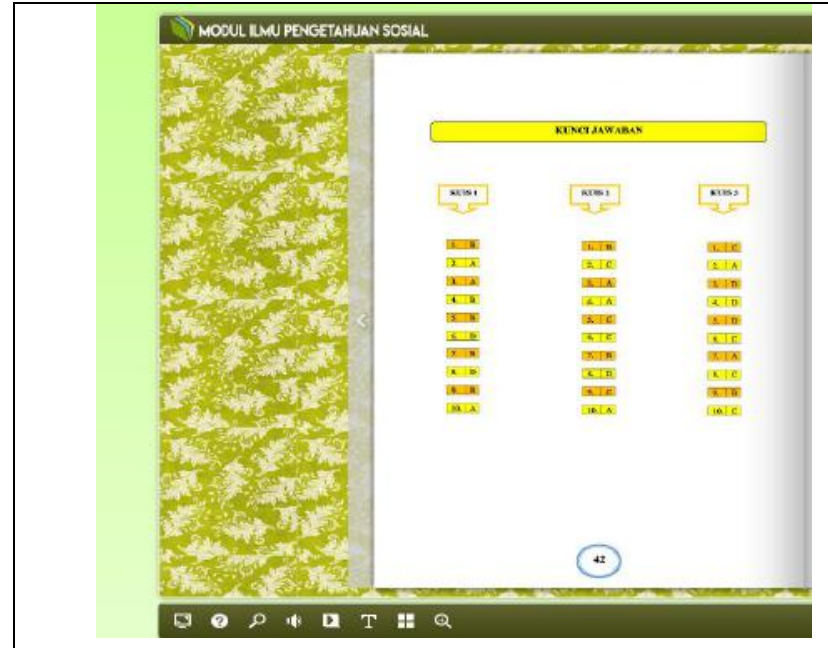

Fig.13: The answer key allows the user to match the answers in the e-social science-based electronic module

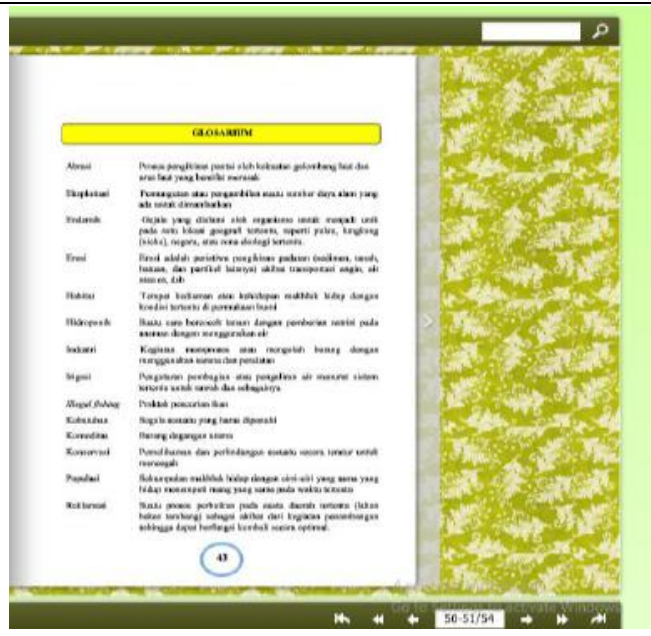

Fig. 14: The glossary allows the user to understand important words or terms in the electronic module.

\section{Validation Results}

The validation of the developed product in the form of an electronic module based on critical ecopedagogy is carried out by experts who are competent in their fields. The results of expert validation obtained are listed in Table 4.
Table 4. Summary of Expert Validation Results

\begin{tabular}{ccc}
\hline Validator & Average Value & Criteria \\
\hline Material Expert & 4,4 & Very Good \\
\hline Media Expert & 4,3 & Very Good \\
\hline Average & 4,4 & Very Good \\
\hline
\end{tabular}

Source: 2020 Research Data Analysis

Table 5. Distribution of Expert Team Assessment

\begin{tabular}{ccccc}
\hline \multirow{2}{*}{ No. } & Interval & Criteria & \multicolumn{2}{c}{ Testing } \\
\cline { 4 - 5 } & & & Frequency & Percentage \\
\hline 1 & $\mathrm{X}>4,21$ & Very Good & 3 & $75 \%$ \\
\hline 2 & $3,40<\mathrm{X} \leq 4,21$ & Good & 1 & $25 \%$ \\
\hline 3 & $2,60<\mathrm{X} \leq 3,40$ & Enough & - & - \\
\hline 4 & $1,79<\mathrm{X} \leq 2,60$ & Lack & - & - \\
\hline 5 & $\mathrm{X} \leq 1,79$ & Very lack & - & $100 \%$ \\
\hline & Amount & & 4 & -
\end{tabular}

Source: 2020 Research Data Analysis

Based on Table 5 and above, it can be seen that the average validation result of material experts is 4.4 and the average result of validation by media experts is 4.3 . So it can be concluded that the average assessment of the expert team on the electronic Social Science module based on ecopedagogy is 4.4 , and it is in an outstanding category. Thus, the ecopedagogy-based electronic module product is feasible to be implemented in learning.

\subsection{Implementation Stage}

This stage is the stage of an ecopedagogy-based electronic module implemented in class VII students of Diponegoro Islamic Junior High School in Surakarta with a limited readability trial.

\section{Limited Readability Trial}

Limited trials of small groups and large groups were carried out to know the practicality and legibility of the product developed. This test was carried out by 
teachers and students because they were both users of the developed ecopedagogy-based electronic module. The results of the ecopedagogy-based electronic module practicality test for student teachers are listed in table 6 . The results of the teacher and student readability assessment are as follows:

Table 6. Readability Test for Teachers and Students

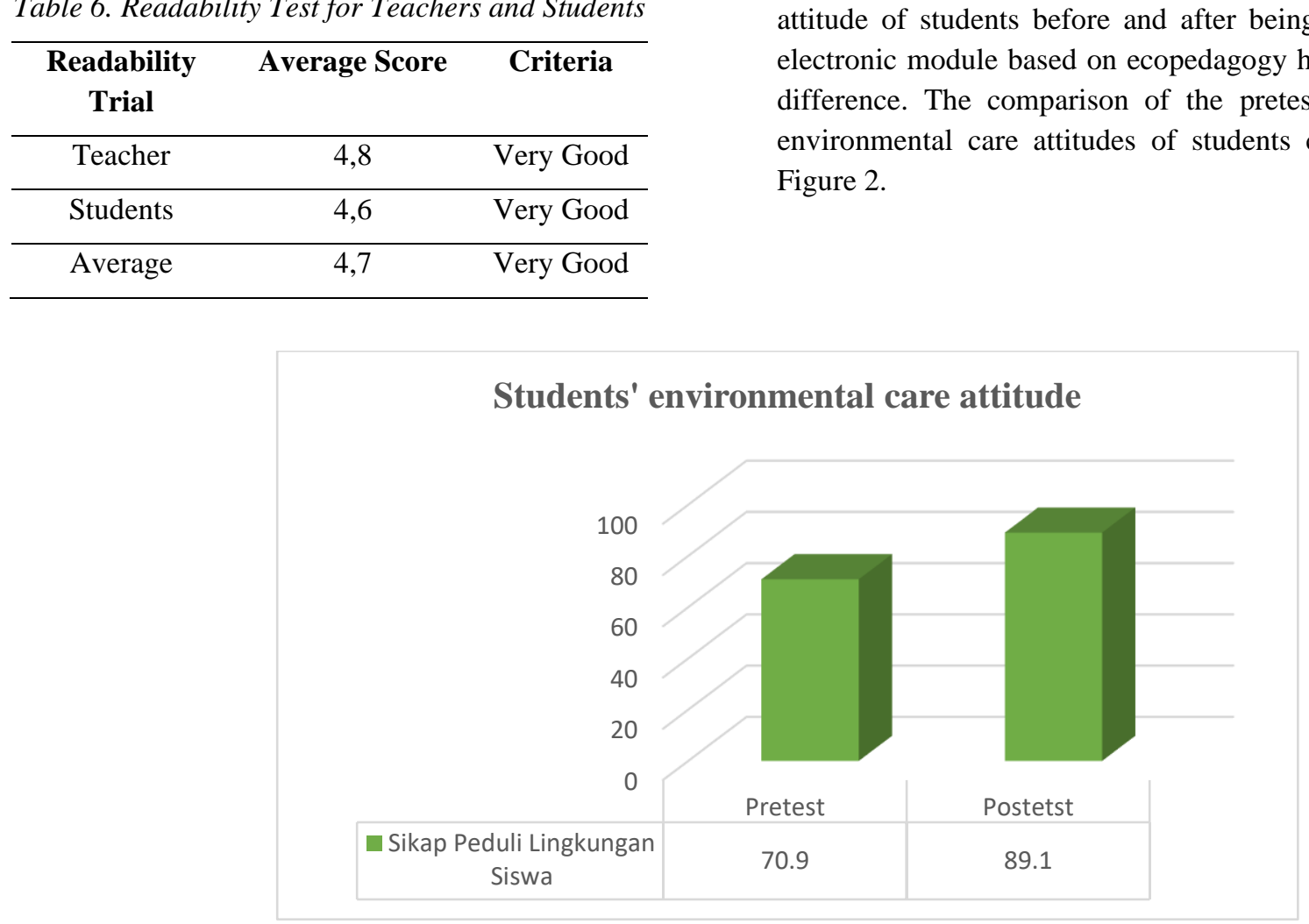

Fig.2: Result of Pre and Post test of Students' Environmental Care Attitudes
Based on the results of the test for the readability of the teacher and students, the average score was 4.7 in the very good category.

\section{Wide-Scale Readability Trials}

Based on the data obtained from the final result test (post-test), it is known that the environmental care attitude of students before and after being taught by the electronic module based on ecopedagogy has a significant difference. The comparison of the pretest and post-test environmental care attitudes of students can be seen in Figure 2.
Based on Figure 2 above, it can be explained that learning with an electronic module based on ecopedagogy has a positive effect on students where the posttest score of 89.1 is higher than the pretest score of 70.9. Thus, it can be concluded that the ecopedagogy-based electronic module has a very significant influence in increasing the environmental care attitude of students. The environmental care attitude of students before implementing (pretest) an ecopedagogy-based electronic module with after the implementation (posttest) an ecopedagogy-based electronic module has a better caring attitude than before the ecopedagogy-based electronic module was implemented. This is in line with Kahn's opinion in Supriatna, (2016: 287-288) argues that ecopedagogy is an alternative approach to educating students and learning communities to live more justly, in harmony with nature and maintaining the values of local wisdom embraced by the community and nature preservation. to support sustainable civilization to change the relationship between humans and the environment today. Ecopedagogy is a way to connect with nature so that it can critically view environmental issues. This means that ecopedagogy can be used as one of the approaches used in the development of the electronic module for Social Science learning, especially in fostering a caring attitude towards the environment.

\subsection{Evaluation Stage}

After going through the previous stages, the development of this ecopedagogy-based electronic module received several improvements that had to be made. The evaluation of the ecopedagogy-based electronic module is carried out based on the assessment sheet, input and suggestions from expert validators and test subjects as users. The evaluation stage is carried out in two parts, namely formative and summative evaluation. Formative evaluation is carried out at every stage of ADDIE 
development. While summative evaluation consists of the final evaluation of the entire ADDIE process.

\section{CONCLUSION}

Research on the development of ecopedagogybased electronic modules is an alternative answer to the use of innovative learning media in the current era of digital technology. Teachers in their duties as facilitators and mediators must always try to develop learning, especially through the use of learning tools (media) that are relevant and following the demands of the times. Therefore, teachers should always be motivated to become innovative teachers, especially in creating learning resources according to student needs.

\section{REFERENCES}

[1] Dick, W., Carey, L., \& Carey, J, O.(2009). The Systematic Design of Instruction. Universitas of South Florida: Emeritu.

[2] Hadzigeorgiou, Y. Skoumios, M. (2013). The development of environmental awareness through school science: Problems and possibilities.International Journal of Environmental \& Science Education Vol 8.

[3] Kollmuss. A. Agyeman, J. (2010). Mind the Gap: Why do people act environmentally and what are the barriers to proenvironmental behavior? Environmental Education Research. Vol 8 (3)

[4] Nasution, D.Q., dkk. 2016. Analisis Kecerdasan Ekologis Berbasis Kearifan Lokal pada Siswa SMA di Desa Jaring Halus Kecamatan Sicanggang dalam Pemanfaatan dan Pelestarian Hutan Mangrove. Jurnal Pendidikan Biologi, Vol.5 No.3: 141-145

[5] Supriatna, Nana. (2016). Ecopedagogy: Membangun Kecerdasan Ekologisdalam Pembelajaran IPS. Bandung: PT. Remaja Rosda Karya

[6] Sudjana, Nana.( 2005). MetodaStatistika. Bandung : PT Tarsito

[7] Sugiyono. (2018). Metodepenelitian Pendidikanpendekatan Kuantitaif, Kualitatif, dan $R \& D$. Bandung: Alfabeta.

[8] Sarkar, M., \& Ara, Q. A. J. (2007). Environmental literacy among the secondary level students: Comparison between urban and rural areas of Natore district. Teacher's World Vol 30-31.

[9] Ozsoy, Sibel. (2012). Can eco-school Improve Elementary School Students' Environmental Literacy Levels?. AsiaPasific Forum On Science Learning and Teaching. Vol 13 